\title{
Audience segmentation to improve targeting of conservation interventions for hunters
}

Jones, Sorrel; Keane, Aidan; St John, Freya A. V.; Vickery, Juliet; Papworth, Sarah

\section{Conservation Biology}

DOI:

10.1111/cobi.13275

Published: 30/08/2019

Publisher's PDF, also known as Version of record

Cyswllt i'r cyhoeddiad / Link to publication

Dyfyniad o'r fersiwn a gyhoeddwyd / Citation for published version (APA):

Jones, S., Keane, A., St John, F. A. V., Vickery, J., \& Papworth, S. (2019). Audience segmentation to improve targeting of conservation interventions for hunters. Conservation Biology, 33(4), 895-905. https://doi.org/10.1111/cobi.13275

\footnotetext{
Hawliau Cyffredinol / General rights

Copyright and moral rights for the publications made accessible in the public portal are retained by the authors and/or other copyright owners and it is a condition of accessing publications that users recognise and abide by the legal requirements associated with these rights.

- Users may download and print one copy of any publication from the public portal for the purpose of private study or research.

- You may not further distribute the material or use it for any profit-making activity or commercial gain

- You may freely distribute the URL identifying the publication in the public portal ?
}

Take down policy

If you believe that this document breaches copyright please contact us providing details, and we will remove access to the work immediately and investigate your claim. 


\title{
Audience segmentation to improve targeting of conservation interventions for hunters
}

\author{
Sorrel Jones, ${ }^{1 *}$ Aidan Keane,${ }^{2}$ Freya St John iD,${ }^{3}$ Juliet Vickery, ${ }^{4}$ and Sarah Papworth (iD) 1 \\ ${ }^{1}$ School of Biological Sciences, Royal Holloway, University of London, Egham, Surrey, TW20 0EX, U.K. \\ ${ }^{2}$ School of GeoSciences, University of Edinburgh, Edinburgh EH9 3JW, U.K. \\ ${ }^{3}$ School of Environment, Natural Resources and Geography, Bangor University, Deiniol Road, Bangor, LL57 2UW, U.K. \\ ${ }^{4}$ Royal Society for the Protection of Birds, The Lodge, Sandy, Bedfordshire, SG19 2DL, U.K.
}

\begin{abstract}
Audience segmentation could belp improve the effectiveness of conservation interventions. Marketers use audience segmentation to define the target audience of a campaign. The technique involves subdividing a general population into groups that share similar profiles, such as sociodemographic or behavioral characteristics. Interventions are then designed to target the group or groups of interest. We explored the potential of audience segmentation for use in defining conservation target groups with a case study of bunters in Liberia. Using 2 data sets describing bousebolds $(\mathrm{n}=476)$ and bunters $(\mathrm{n}=205)$, we applied a clustering method in which infinite binomial mixture models group bunters and households according to livelibood and behavior variables and a simple method to define target groups based on bunting impact (bunting bousebolds and high-impact bunters). Clusters of bunters and bousebolds differed in their experiences with confiscation of catch at roadblocks and participation in livelibood-support programs, indicating that these interventions operate unevenly across subsets of the population. By contrast, the simple method masked these insights because profiles of hunting bousebolds and bigh-impact bunters were similar to those of the general population. Clustering results could be used to guide the development of livelibood and regulatory interventions. For example, a commonly promoted agricultural activity, cocoa farming, was practiced by only 2\% (out of 87) of the largest bunter cluster of nonlocal gun bunters but was prevalent among local trappers, suggesting that assistance aimed at cocoa farmers is less appropriate for the former group. Our results support the use of audience segmentation across multiple variables to improve targeted intervention designs in conservation.
\end{abstract}

Keywords: bushmeat, conservation marketing, Gola Forest, hunting, livelihood support, target audience, West Africa

Segmentación del Público para Mejorar la Focalización de las Intervenciones de Conservación para los Cazadores

Resumen: La segmentación del público podría ayudar a mejorar la efectividad de las intervenciones de conservación. Los publicistas utilizan la segmentación del público para definir al público focal de una campaña. La técnica incluye la subdivisión de una población general en grupos que comparten perfiles similares, como las características socio-demográficas o de comportamiento. Después se diseñan las intervenciones para enfocarse en el grupo o los grupos de interés. Exploramos el potencial de la segmentación del público en el uso de la definición de grupos con objetivos de conservación usando el estudio de caso de los cazadores en Liberia. Con dos conjuntos de datos de descripciones de los bogares $(\mathrm{n}=476)$ y de los cazadores $(\mathrm{n}=205)$ aplicamos un método de agrupación en el cual los modelos de mezcla binomial infinita agruparon a los cazadores y a los hogares de acuerdo a las variables de sustento y de comportamiento. También aplicamos un método simple para definir los grupos focales con base en el impacto de la caza (hogares de cazadores y cazadores de alto impacto). Los grupos de cazadores y de bogares difirieron en experiencias con la confiscación de la caza en retenes y en participación dentro de programas de apoyo al sustento, lo que indica que estas

*email sorrel.jones.2016@live.rbul.ac.uk

Article impact statement: Audience segmentation defines bunter groups for conservation intervention.

Paper submitted June 20, 2018; revised manuscript accepted November 16, 2018.

This is an open access article under the terms of the Creative Commons Attribution License, which permits use, distribution and reproduction in any medium, provided the original work is properly cited. 
intervenciones operan disparejamente en los subconjuntos de la población. En contraste, el método simple enmascaró estas percepciones ya que los perfiles de los bogares de cazadores y de los cazadores de alto impacto fueron similares a los de la población general. La agrupación de los resultados podría usarse para guiar el desarrollo del sustento y de las intervenciones regulatorias. Por ejemplo, el cultivo de cacao, una actividad agrícola que se promueve frecuentemente, sólo lo practicaba el 2\% (de 87) del mayor grupo de cazadores de los cazadores armados no locales, pero fue prevaleciente entre los trampeadores locales, lo que sugiere que la asistencia enfocada hacia los cultivadores de cacao es menos apropiada para el primer grupo. Nuestros resultados respaldan el uso de la segmentación del público en múltiples variables para mejorar los diseños de intervenciones focalizadas en la conservación.

Palabras clave: África occidental, apoyo al sustento, bosque de Gola, cacería, carne de caza, mercadotecnia de la conservación, público focal

\begin{abstract}
摘要: 受众细分有助于提高保护干预措施的有效性。市场营销者用受众细分来确定活动的目标受众, 这项方法 涉及将一般人群划分为具有相似特征 (如社会人口统计学或行为特征) 的多个亚群, 然后针对一个或多个亚群来 设计干预措施。我们以利比亚的狩猎者为例, 探讨了受众细分在确定保护的目标群体方面的应用潜力。我们利 用描述家庭 $(\mathrm{n}=476)$ 和狩猎者 $(\mathrm{n}=205)$ 的两个数据集, 采取聚类方法根据生计和行为变量用无限二项混合 模型对狩猎者和家庭进行分类, 同时用一个简单方法根据狩猎影响确定了目标群体 (狩猎家庭和高影响狩猎者) 狩猎者和家庭聚类群集间的差别在于在路障检查中被没收猎获物的经历和生计支持项目的参与情况, 表明干 预措施不能均衡地作用于人群的不同亚群。相比之下, 用简单方法不能得到这些发现, 因为狩猎家庭和高影响猎 人与普通人群的特征相似。聚类结果还可用于指导生计发展和监管干预。举例来说, 对于当地大力推广的可可 种植这项农业活动, 外来用枪狩猎者的最大聚类群集中只有 $2 \%$ 的人 (共 87 人) 参与, 但在本地设陷阱的人中参 与度却很高, 这表明针对可可种植者的援助并不适用于前者。我们的结果支持了利用考虑多个变量的受众细分 来提高保护中的针对性干预措施的设计。[翻译: 胡怡思; 审校: 聂永刚]
\end{abstract}

关键词: 保护市场学, 丛林肉, 戈拉森林, 生计支持, 目标受众, 西非, 狩猎

\section{Introduction}

Conservation practitioners are frequently faced with the challenge of influencing human behavior and must make choices about which approach to use in any given site. Conservation interventions are typically implemented using a combination of actions that require managers to make site-specific decisions about which to use. Such decisions should be based on a clear understanding of who the action intends to influence (Veríssimo 2013; Reddy et al. 2017) given that different types of people are likely to be responsive to different mechanisms (Kotler \& Lee 2008). An appropriately defined target group is therefore fundamental to guide intervention design, yet many projects either fail to specify who they aim to influence or employ a broad definition such as all residents within a geographic area (Spiteri \& Nepal 2006). As a result, intervention designs may be broadly aimed at an average person across an entire community, which is inefficient if the population is comprised of heterogeneous groups responding differently to interventions (Agrawal \& Gibson 1999; Wright et al. 2015). Intervention designs may be improved by paying greater attention to the process and methods of defining target groups.

Techniques from marketing may be well suited to improve the way target groups are defined in conservation. Audience segmentation is a commonly used approach of subdividing populations into groups with shared characteristics, such as sociodemographic, behavioral, or psychographic profiles (Wedel \& Kamakura 2012).
Ideally, segmentation defines groups of individuals who can be expected to respond similarly to interventions, allowing managers to design approaches that are oriented to target the specific group or groups of interest (Kotler \& Lee 2008). Effective segmentation depends on selecting appropriate characteristics for defining groups (Wedel \& Kamakura 2012). These should be variables linked to behavior and which have practical consequences for management decisions. Attributes most commonly used in marketing include broad demographic, socioeconomic, and geographic factors, but increasingly focus is on individual traits, such as personality, attitudes, beliefs, lifestyle, risk preference, and social group affiliations (Lee et al. 2014; Hardcastle \& Hagger 2016).

Segmentation has rarely been applied in conservation, but it is a valuable tool in social marketing (Kotler \& Lee 2008). For example, segmentation has been used to design public health campaigns that target those most at risk (Forthofer \& Bryant 2000; Dietrich et al. 2015) or most likely to be responsive to interventions (Rimal et al. 2009). Key environmental problems, such as climate change, energy use, transport, and sustainable lifestyle choices, have also been the subject of segmentation studies to guide policy and messaging campaigns (Anable 2005; Maibach et al. 2011; McKenzie-Mohr et al. 2011; Poortinga \& Darnton 2016). In a rare example of segmentation in conservation, Zabala et al. (2017) applied the approach to guide the introduction of conservation-friendly farming practices in Mexico by using attitude statements of farmers to define groups 
of early adopters and followers. Harrison et al. (2015) also used a straightforward segmentation of authorized versus unauthorized resource users to generate valuable management insight in a Ugandan protected area.

There are currently no methodological guidelines to inform the process of defining target groups in conservation, despite this being of great practical interest to managers. Methods used within marketing to subdivide populations range from the relatively simplistic approach of splitting populations according to single variables, to more complex clustering approaches that differentiate groups across multiple variables (Wedel \& Kamakura 2012). A major challenge in conservation is the gap in understanding of factors that underpin behavior. Detailed psychographic data sets of the sort used in marketing studies are rarely available or difficult to obtain where target behaviors are illegal (Gavin et al. 2010). Given these typical constraints, segmentation based on multiple variables may perform little better than simplistic target group definitions based on a single trait, such as whether or not someone hunts. Multivariate methods may have higher costs associated with data collection and analysis, so a practical management consideration is whether these costs are justified by improved conservation outcomes.

We evaluated segmentation approaches with a case study of bushmeat hunting in the Gola Forest, Liberia. Hunting reduction is a conservation priority for many sites across the tropics (Benítez-López et al. 2017; Cronin et al. 2017). However, bushmeat provides a valuable source of food and income for rural populations who are often economically vulnerable (e.g., Fa et al. 2003). Therefore, many hunting reduction programs have a human welfare element (Davies 2002), and interventions generally fall into 5 categories: support for sustainable livelihoods; provision of alternative protein sources; financial mechanisms; regulatory and enforcement mechanisms; and education and awareness raising campaigns (van Vliet 2011). The most effective hunting interventions are likely to be highly context specific, so managers require a clear understanding of the intended target group or groups to guide intervention design.

We assessed the usefulness of 2 audience-segmentation methods under realistic constraints of site-based conservation programs: a cluster method, where groups were differentiated based on multiple variables describing livelihoods and behavior, and a simple method, where the population was divided into 2 groups of either high or low hunting impact. We asked do segmentation methods generate insights to guide decisions about appropriate livelihood support interventions and does either segmentation approach (cluster or simple) differentiate groups with profiles that suggest targeted intervention design is appropriate?

\section{Methods}

\section{Study Site}

We collected data from July 2016 to July 2017 in Kongba district, Liberia, at the site of a community-based conservation project, GolaMA, which started in 2014 (GRNP 2015). Project activities focused on establishment of conservation-friendly community forests, based on livelihood-support approaches and hunting regulations. Overhunting is a primary conservation threat in Liberia. Wild meat is consumed widely (Junker et al. 2015; Ordaz-Németh et al. 2017) and thus provides substantial income for hunters and traders (Hoyt 2004; Greengrass 2016). Hunting of species listed as protected under the Wildlife Act (1988, revised 2016) is illegal, as is hunting in national parks, although both types of hunting are widespread (S.J., personal observation). The Gola Forest National Park (established 2016) is adjacent to the study site, and wild meat being transported to the capital city of Monrovia is irregularly confiscated at a checkpoint. The west of the study area extends to the Sierra Leone border and is a short distance from the Gola Rainforest National Park (Fig. 1).

The site retains relatively high forest cover and low population density. Economic immigration for mining, logging, and hunting has resulted in an ethnically diverse population with 20 tribes represented. At the time of the study, two-thirds of the population (65\%) belonged to 1 of 3 dominant tribes (Gola, Mende, and Kissi) (Supporting Information). Residents self-identify as local or nonlocal citizens. Those who consider themselves local typically have at least 1 parent with local ancestry. Residents who identify as nonlocal are typically individuals born outside the district or without local ancestry, such that long-term residents and recent arrivals may identify as nonlocal. The largest group of nonlocals was from Nimba county in Liberia (about $26 \%$ of nonlocals), and $15 \%$ of all residents were Sierra Leonean nationals. At least $7 \%$ of the population was transient migrants.

\section{Data Collection}

We collected data through questionnaires administered during face-to-face interviews (Supporting Information). Hunting is an everyday activity in Liberia and is practiced openly, but some degree of social desirability bias is likely given that it is illegal (Nuno \& St John 2014). However, an initial pilot study suggested that most hunters were willing to talk openly about their activities, and we judged the level of bias in data obtained from direct questioning to be acceptably low for our purposes. Ethical approval for the use of human subjects was obtained from the Royal Holloway University of London Research Ethics Committee.

The sample included 18 villages, consisting of all villages that participated in the GolaMA conservation 

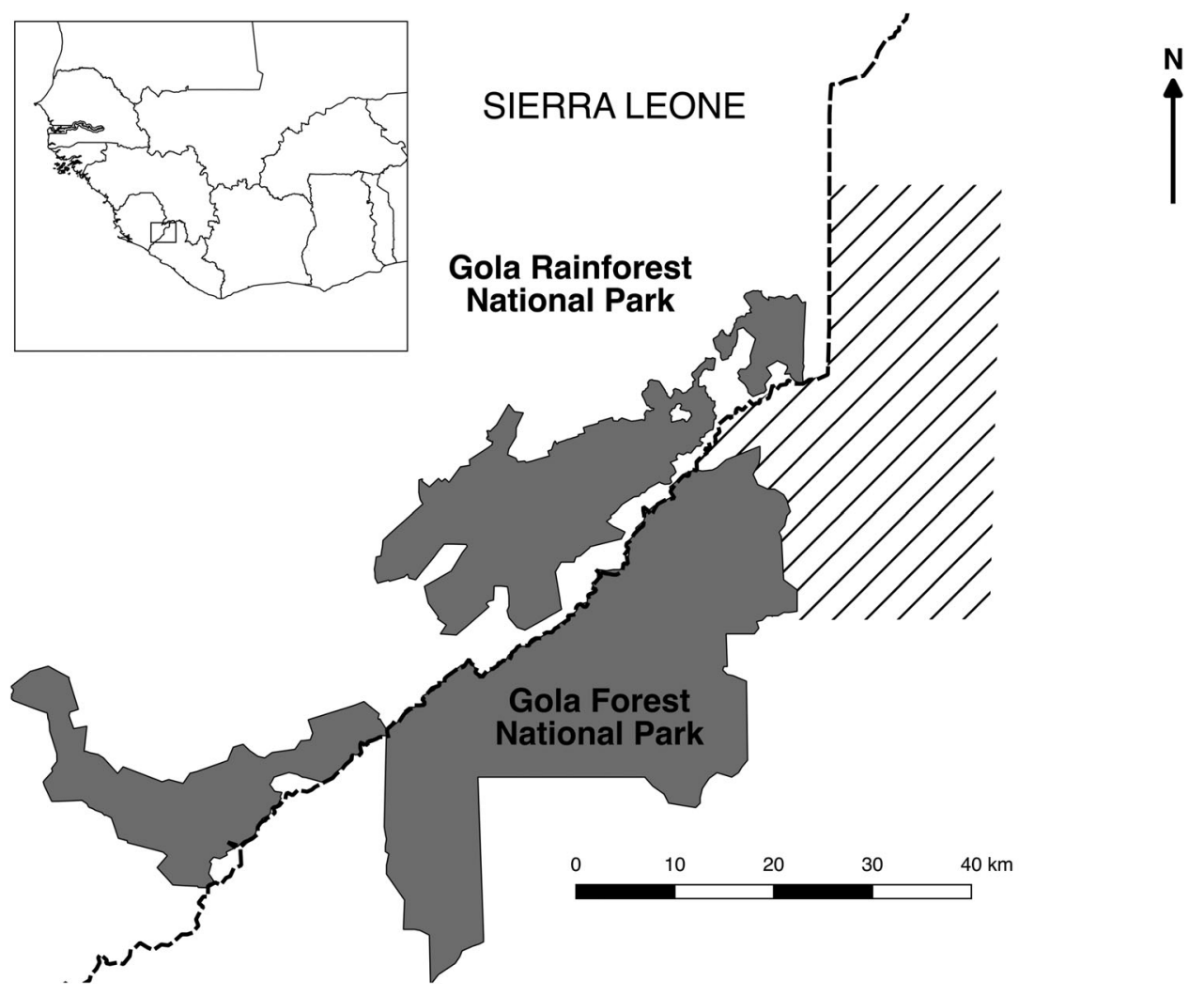

\author{
Figure 1. Study site location \\ (diagonal lines) in Liberia \\ (gray, protected areas; \\ dashed line, border).
}

project and 2 neighboring villages (Fig. 1). The latter were selected based on their geographic proximity and had similar sociodemographic characteristics. In each village, we surveyed households and hunters separately. The household survey included all households, except in the largest village where an estimated $60 \%$ of households were surveyed (mean households per village $=28$, range $=2-111$ ). The hunter survey included all identified hunters in all villages and semipermanent camps that came under village jurisdiction (mean hunters per village $=10.8$, range $=0-28$ ). Hunters were identified during the household survey, through key informants and snow-ball sampling. If a hunter or household was not initially available, interviewers returned at least 3 times. It was not possible to match the hunter and household surveys because hunters were rarely encountered at their homes, and nonunique names created ambiguity in determining which household a hunter belonged to.

Questionnaires for the household survey were used to obtain information about livelihood activities and demography, and those for hunters contained additional questions about hunting behavior (Table 1). Estimates of mean biomass harvest for each hunter were derived from the total estimated body mass of their most recent catch, divided by the duration of both the hunting trip and days spent resting in the town. Hunters reported the composition of their last catch and the total estimated body mass was calculated using mean adult values for each species from Kingdon (2015) and Jones et al. (2009).

\section{Simple and Cluster Methods}

We defined 2 simple target groups: hunting households, based on the household survey, and high-impact hunters, based on the hunter survey (Table 1).

We performed separate cluster analyses on the household and hunter data sets with infinite binomial mixture models implemented with the $\mathrm{R}$ package BayesBinMix (R Core Development Team 2014; Papastamoulis \& Rattray 2017). Cluster assignment used the equivalence classes representative algorithm (Papastamoulis 2014). A truncated Poisson distribution was used as the prior distribution for cluster number, allowing a maximum of 20 clusters. We used a metropolis-coupled Markov chain Monte Carlo sampling algorithm with parallel tempering to improve mixing. Fifteen heated parallel chains were run with 20,000 iterations. Convergence was assessed with the Geweke diagnostic (Geweke 1992).

Variables used for clustering related to livelihood activities, citizenship, and hunting behavior are listed in Table 1. Livelihood activities relevant to intervention design and principle candidates for support interventions by the GolaMA project were cocoa farming, palm farming, small-scale mining, and petty-goods trading. These variables were chosen to be simple for managers to interpret without prior knowledge of which factors mediate behavior and which could be measured where psychological scales have yet to be developed and validated. Incorporating a broader set of sociodemographic 
Table 1. Variables and criteria used to define hunter and household target groups for conservation interventions.

\begin{tabular}{|c|c|c|c|}
\hline \multirow[t]{2}{*}{ Cluster method } & $\begin{array}{l}\text { citizenship } \\
\text { livelihood activities }\end{array}$ & $\begin{array}{l}\text { household head is local } \\
\text { palm farming } \\
\text { cocoa farming } \\
\text { small-scale mining } \\
\text { petty-goods trading } \\
\text { biennial agriculture } \\
\text { annual agriculture } \\
\text { charcoal production } \\
\text { fishing } \\
\text { salaried employment }\end{array}$ & $\begin{array}{l}\text { hunter is local } \\
\text { palm farming } \\
\text { cocoa farming } \\
\text { small-scale mining } \\
\text { petty-goods trading } \\
\text { skilled craft }\end{array}$ \\
\hline & hunting behavior & $\begin{array}{l}\text { hunting by any household } \\
\text { member }\end{array}$ & $\begin{array}{l}\text { harvested biomass }>8.5 \mathrm{~kg} / \mathrm{d} \\
\text { hunts }>14 \mathrm{~d} / \text { month } \\
\text { uses gun } \\
\text { uses snares } \\
\text { estimated income }>\$ 100 / \mathrm{d} \text { hunting }\end{array}$ \\
\hline Simple method & hunting behavior & $\begin{array}{l}\text { hunting by any household } \\
\text { member (hunting households) }\end{array}$ & $\begin{array}{l}\text { hunters with highest per capita } \\
\text { impact collectively responsible for } \\
50 \% \text { of total harvest in study } \\
\text { (high-impact hunters) }\end{array}$ \\
\hline
\end{tabular}

*The cluster method defines groups based on their similarity across multiple binomial variables, the simple method defines groups from a single criterion.

and psychographic variables was beyond the scope of this study, which is intended to provide an initial assessment of segmentation in a novel context. Continuous variables were transformed to binary responses with cutoff values selected to provide straightforward management interpretations. Biomass harvest was coded as 1 for values exceeding the mean body mass of the most frequently killed species (maxwell's duiker [Philantomba maxwelli]) and hunters' self-estimated profit was coded as 1 if in excess of US\$100/month, a typical entry wage from local employment sources.

\section{Generation of Insights to Guide Intervention Targeting}

Livelihood profiles represent basic information to guide decisions about appropriate livelihood support interventions. We compared the prevalence of livelihood activities in clusters and simple groups with those of the complete data sets to explore whether segmentation supplied novel perspectives. Group profiles were supplemented with qualitative descriptions based on sociodemographic information: age, marital status, education, and household size. We defined education as high school level if hunters had at least 6 years of formal education (hunter data set) or if any member of the household did (household data set).

Segmentation should group people who may respond similarly to a given intervention in order to guide intervention targeting. Interventions had not been fully implemented at the time of the study, so direct measures of intervention response were unavailable. Instead, we tested whether groups differed for the following indirect measures. For households, we evaluate participation in livelihood support programs being piloted by the GolaMA project because this could indicate future participation (Ajzen 2011). Available programs were beekeeping, cocoa farmer training, small loans groups, and community agriculture. We considered only villages where at least 1 program was offered and combined programs so households either did or did not engage in a livelihood intervention. For hunters, we evaluated killing of any of 4 high-profile protected species (forest elephant [Loxodonta cyclotis], pygmy hippopotamus [Hexaprotodon liberiensis], western chimpanzee [Pan troglodytes verus], or leopard [Panthera pardus]) and experience of confiscation of catch by authorities, usually taking place at road blocks. The former indicated hunters with the means and disposition to target largebodied species, which are widely known to be protected by law, and the latter was a combined measure of both exposure to and tolerance of law enforcement efforts.

We use Pearson's chi-square to evaluate distribution of these traits between clusters and simple target groups. Analysis of variance was used to evaluate group differences in age and household size.

\section{Results}

\section{Hunting in the Study Area}

Of the $\mathbf{4 7 6}$ households in the survey, 39\% had members who hunted and $26 \%$ had been hunting during the 
Table 2. Descriptive summary of household groups based on results of cluster analysis.

\begin{tabular}{|c|c|c|c|c|}
\hline Housebold group & $n$ & $\begin{array}{c}\text { Citizensbip and } \\
\text { bunting prevalence }\end{array}$ & $\begin{array}{c}\text { Livelibood activities bigh } \\
\text { prevalence }\end{array}$ & $\begin{array}{c}\text { Livelibood activities low } \\
\text { prevalence }\end{array}$ \\
\hline Nonlocal farmers & 128 & $\begin{array}{l}96 \% \text { nonlocal } \\
61 \% \text { hunt }\end{array}$ & $\begin{array}{l}\text { annual agriculture } 98 \% \\
\text { petty-goods trade } 70 \% \\
\text { palm farming } 51 \% \\
\text { mining } 38 \%\end{array}$ & $\begin{array}{l}\text { cocoa } 27 \% \\
\text { charcoal production } 9 \%\end{array}$ \\
\hline Local farmers & 176 & $\begin{array}{l}100 \% \text { local } \\
40 \% \text { hunt }\end{array}$ & $\begin{array}{l}\text { annual agriculture } 97 \% \\
\text { cocoa } 89 \% \\
\text { petty-goods trade } 65 \%\end{array}$ & $\begin{array}{l}\text { salaried employment } 0 \% \\
\text { mining } 15 \%\end{array}$ \\
\hline $\begin{array}{l}\text { Nonlocal hunting } \\
\text { households }\end{array}$ & 31 & $\begin{array}{l}84 \% \text { nonlocal } \\
97 \% \text { hunt }\end{array}$ & hunting $97 \%$ & $\begin{array}{l}\text { annual agriculture } 16 \% \\
\text { cocoa } 0 \%\end{array}$ \\
\hline $\begin{array}{l}\text { Merchants and salaried } \\
\text { workers }\end{array}$ & 63 & $\begin{array}{l}74 \% \text { local } \\
3 \% \text { hunt }\end{array}$ & $\begin{array}{l}\text { petty-goods trade } 98 \% \\
\text { salaried employment } 49 \%\end{array}$ & hunting 3\% \\
\hline Nonlocal miners & 68 & $\begin{array}{l}81 \% \text { nonlocal } \\
12 \% \text { hunt }\end{array}$ & $\begin{array}{l}\text { mining } 97 \% \\
\text { petty-goods trade } 89 \% \\
\text { charcoal production } 32 \%\end{array}$ & $\begin{array}{l}\text { cocoa } 4 \% \\
\text { palm farming } 3 \%\end{array}$ \\
\hline Local plantation farmers & 10 & $\begin{array}{l}90 \% \text { local } \\
0 \% \text { hunt }\end{array}$ & $\begin{array}{l}\text { annual agriculture } 100 \% \\
\text { cocoa } 90 \% \\
\text { palm farming } 60 \%\end{array}$ & $\begin{array}{l}\text { fishing } 0 \% \\
\text { mining } 0 \% \\
\text { petty-goods trade } 0 \%\end{array}$ \\
\hline
\end{tabular}

previous week. Local citizens headed $54 \%$ of all households and $45 \%$ of hunting households. Of the 205 hunters interviewed in the survey, 41\% were local citizens, $75 \%$ used guns to hunt, and 56\% used snares. Mean trip length was $3.9 \mathrm{~d}$ (SD 3.0) and mean estimated biomass harvest was $14.4 \mathrm{~kg} / \mathrm{d}$ (SD 14.5).

\section{Household Clusters}

The most likely number of clusters was 6 (probability 0.53). Size varied from 10 to 176 households. The 2 largest clusters held $64 \%$ of all households. Citizenship was a prominent feature defining clusters (Table 2); the largest cluster held almost $70 \%$ of all local-headed households. High school education (of any household member) was unevenly distributed across clusters ( $n=$ 471, $\chi^{2}=15.09$, df $\left.=5, p<0.01\right)$. The clusters were labeled for convenience (Table 2). Local farmers had a relatively low rate of high school education (37\%) compared with $60 \%$ for nonlocal hunting households, merchants, salaried workers, and local plantation farmers (Supporting Information).

The cluster of nonlocal farmers contained 128 households, of which 96\% were nonlocal. Most (98\%) practiced annual or biennial agriculture. The majority (61\%) were hunting households-representing $40 \%$ of all hunting households in the sample. Relatively common nonhunting activities were petty-goods trade (70\%), palm farming ( $51 \%$ ), and mining (38\%).

The cluster of local farmers contained 176 households, all of which were local. Hunting was practiced by $40 \%$ of these households. Most households (97\%) practiced annual or biennial agriculture, $89 \%$ were cocoa farming households, and $65 \%$ traded petty goods. Mean household size was the largest of any group (mean number of adults 3.4 [SD 2.1], mean children 3.8 [SD 1.8]) (Supporting Information).

The cluster of nonlocal hunting households contained 31 households, of which 84\% were nonlocal and $97 \%$ hunted. None were cocoa farming households, and few farmed annual or biennial crops (16\% and $23 \%$, respectively), distinguishing this group from the nonlocal farmers, many of whom also hunted.

The merchant and salaried workers' cluster contained 63 households, of which $74 \%$ were local and 3\% hunted. Most (98\%) traded petty goods, and 49\% had some form of employment-representing $66 \%$ of all households with employment.

The nonlocal miners' cluster contained 68 households, of which $81 \%$ were nonlocal, $97 \%$ engaged in mining, and $12 \%$ hunted. Cocoa and palm farming were rare $(4 \%$ and $3 \%$, respectively). Most ( $72 \%$ ) were resident in the same village. Households had fewer children on average than other groups (mean $[\mathrm{SD}]=2.1$ [1.7] compared with 3.3 [1.9] across all households) (Supporting Information).

The cluster of local plantation farmers was the smallest (10 households), and all households farmed cocoa or palm, grew subsistence crops, and gained additional income from selling charcoal, but they lacked other income sources. No households hunted. Six were resident in the same village. 
Table 3. Descriptive summary of hunter groups based on results of cluster analysis.

\begin{tabular}{|c|c|c|c|c|c|}
\hline $\begin{array}{l}\text { Nonlocal gun } \\
\text { hunters }\end{array}$ & 87 & $\begin{array}{l}98 \% \text { nonlocal } \\
100 \% \text { use guns } \\
49 \% \text { use snares }\end{array}$ & $\begin{array}{l}\text { mining } 24 \% \\
\text { petty-goods trade } 22 \%\end{array}$ & $\begin{array}{l}\text { cocoa } 2 \% \\
\text { palm farming } 9 \%\end{array}$ & $\begin{array}{l}\text { intermediate offtake } 14.1 \mathrm{~kg} / \mathrm{d} \\
(12.8) \\
\text { high effort } 14.7 \mathrm{~d} / \text { month }(5.32) \\
\text { intermediate income (61\% earn } \\
\text { over } \$ 100 / \text { month) }\end{array}$ \\
\hline $\begin{array}{r}\text { Local gun } \\
\text { hunters }\end{array}$ & 49 & $\begin{array}{l}90 \% \text { local } \\
100 \% \text { use guns } \\
17 \% \text { use snares }\end{array}$ & $\begin{array}{l}\text { cocoa } 55 \% \\
\text { skilled craftsmen } 14 \%\end{array}$ & mining $8 \%$ & $\begin{array}{l}\text { low offtake } 11.8 \mathrm{~kg} / \mathrm{d}(16.5) \\
\text { low effort } 8.78 \mathrm{~d} / \mathrm{month}(4.42) \\
\text { intermediate income }(62 \% \text { earn } \\
\text { over } \$ 100 / \text { month })\end{array}$ \\
\hline $\begin{array}{l}\text { Nonlocal } \\
\text { trappers }\end{array}$ & 28 & $\begin{array}{l}85 \% \text { nonlocal } \\
0 \% \text { use guns } \\
100 \% \text { use snares }\end{array}$ & petty-goods trade $29 \%$ & $\begin{array}{l}\text { cocoa } 7 \% \\
\text { palm farming } 4 \%\end{array}$ & $\begin{array}{l}\text { intermediate offtake } 14.8 \mathrm{~kg} / \mathrm{d} \\
(15.3) \\
\text { intermediate effort } 11.4 \mathrm{~d} / \mathrm{month} \\
(5.16) \\
\text { low income (15\% earn over } \\
\$ 100 / \text { month) }\end{array}$ \\
\hline $\begin{array}{c}\text { Occasional } \\
\text { hunters }\end{array}$ & 10 & $\begin{array}{l}80 \% \text { local } \\
90 \% \text { use guns } \\
80 \% \text { use snares }\end{array}$ & $\begin{array}{l}\text { petty-goods trade } \\
100 \% \\
\text { cocoa } 90 \% \\
\text { palm } 80 \% \\
\text { mining } 70 \%\end{array}$ & none & $\begin{array}{l}\text { low offtake } 10.8 \mathrm{~kg} / \mathrm{d}(7.07) \\
\text { low effort } 8.4 \mathrm{~d} / \text { month }(5.36) \\
\text { low income (none earn over } \\
\$ 100 / \text { month) }\end{array}$ \\
\hline
\end{tabular}

\section{Hunter Clusters}

Hunters fell into 5 clusters (probability of 0.58 ). Size ranged from 10 to 87 hunters. Citizenship and hunting methods were prominent defining features (Table 3). Marital status or number of children was not associated with cluster membership. Age differed significantly between clusters $\left(F_{4,194}=4.16, p<0.01\right)$. High school education was not evenly distributed across clusters $\left(n=202, \chi^{2}=10.03, \mathrm{df}=4, p=0.04\right)$ (Supporting Information).

The cluster of nonlocal gun hunters contained 87 hunters, $98 \%$ of whom were nonlocal citizens (residents with nonlocal ancestry). Mean residency in villages was 9.2 years (SD 5.1). All used guns. Most hunted over $14 \mathrm{~d} /$ month $(78 \%)$, and $61 \%$ generated over $\$ 100 /$ month. Mining and petty trading were practiced by some individuals ( $24 \%$ and $22 \%$, respectively), but other income sources were rare. Rates of high school education were the highest of any group ( $47 \%$ relative to $35 \%$ among all hunters).

The cluster of local trappers contained 31 hunters; $87 \%$ were local and all used snares. Mean offtake per hunter was higher than any other group $(19.7 \mathrm{~kg} / \mathrm{d})$, but only $33 \%$ spent over $14 \mathrm{~d}$ per month hunting. Income from palm, cocoa, and mining was relatively common
(65\%, $48 \%$, and $23 \%$, respectively). Local trappers were younger than nonlocal gun hunters (mean age $[\mathrm{SD}]=$ 34.6 years [10.7] and 43.6 years [11.1], respectively, Tukey test difference in means $=9.0,95 \%$ CI 2.7-15.3, $p<0.01$ ). Only $26 \%$ had high school education.

The cluster of local gun hunters contained 49 hunters, $90 \%$ were local and all used guns. Despite relatively low offtake (mean $=10.8 \mathrm{~kg} / \mathrm{d}$ ), most generated over $\$ 100 /$ month (62\%). This group showed the highest prevalence of skilled crafts people (14\%) and few miners (8\%). Cocoa and palm were relatively common (55\%, $37 \%$, respectively). Mean residency in villages was longer than any group (mean $[\mathrm{SD}]=24.1$ years $[17.0]$ relative to mean $[\mathrm{SD}]=14.4$ years $[12.8]$ among all hunters) (Supporting Information).

The nonlocal trapper cluster contained 28 hunters, of which $85 \%$ were nonlocal. All only used snares to hunt. Effort and offtake were intermediate, but only $15 \%$ generated over $\$ 100 /$ month. There was low prevalence of income from nonhunting livelihoods. Members had settled in villages relatively recently compared with other groups (mean residency $[\mathrm{SD}]=8.5$ years $[8.0]$ ) (Supporting Information).

The cluster of occasional hunters contained only 10 members. Eight were local and 9 used guns. Most had multiple income sources. All were petty traders, and 
cocoa, palm, and mining were prevalent. None earned over \$100/month, and most (90\%) spent under 14 $\mathrm{d} /$ month hunting.

\section{Generation of Insights to Guide Intervention Targeting}

The cluster method produced groups which differed in livelihood profiles compared to the simple method of no targeting for households and hunters. Among 4 activities considered candidates for support interventions, the most prevalent was petty trading among all households (no targeting, 73\%) and hunting households (simple targeting, 72\%), but cocoa farming among the largest cluster of local farmers (89\%). The prevalence of livelihood activities in the simple target groups was generally similar to the general population (Supporting Information).

Among hunters, mining was prevalent in the largest cluster of nonlocal gun hunters (24\%), whereas this consistently ranked below other activities under simple or no targeting (Supporting Information). Livelihood activity profiles of hunters differed from those of households, with prevalence of petty trading being much higher among households (72\%) than hunters (23\%).

Pilot livelihood support programmes were offered to 184 households, of which $82 \%$ (151 households) participated. It was not possible to test whether participation was evenly distributed across all clusters because low expected values for small clusters violated the assumptions of Pearson's chi-square test. Therefore, we only compared the 2 largest clusters. Participation was unevenly distributed $\left(n=156, \chi^{2}=6.23\right.$, df $=1, p$ $=0.013)$. Nonlocal farmer households had lower participation ( $67 \%$ of 39 households) than the expected value of $81.4 \%$, whereas local farmers had higher participation (86\% of 117 households). In contrast, participation had no significant association with the simple target groups of hunting and nonhunting households (85\% of 66 hunting households and 81\% of 118 nonhunting households participated, $n=184, \chi^{2}=0.29$, df $=1, p=0.59$ ).

Prevalence of killing any of 4 protected species was $42 \%$ across all hunters who were asked this question ( $n$ $=131$ ). A total of $34 \%$ had killed western chimpanzee during their hunting career, 18\% had killed pygmy hippopotamus, $18 \%$ had killed leopard, and $2 \%$ had killed forest elephant. There was no association between prevalence of protected species killing and groups defined using either the simple or cluster method (Table 4) $\left(n=131\right.$, simple method: $\chi^{2}=2.26 \mathrm{df}=1$, $p=0.13$; cluster method: $\chi^{2}=6.95$, df $=4, p=0.14$ ). This was also true for western Chimpanzees specifically $\left(n=131\right.$, simple method: $\chi^{2}=1.01$, df $=1, p=0.31$; cluster method $\chi^{2}=1.01$, $\mathrm{df}=1, p=0.31$ ). It was not possible to evaluate the other species individually due to low expected values which violated test assumptions.

A total of $45 \%$ of hunters had previously had their catch confiscated by authorities. This was significantly
Table 4. Protected species killing and catch confiscation among hunter groups defined based on the cluster and simple methods.

\begin{tabular}{|c|c|c|}
\hline Metbod & $\begin{array}{c}\text { Proportion that } \\
\text { killed a protected } \\
\text { species } \\
\text { (sample size) }\end{array}$ & $\begin{array}{l}\text { Proportion that } \\
\text { experienced } \\
\text { confiscation } \\
\text { (sample size) }\end{array}$ \\
\hline Cluster & $\begin{array}{c}\chi^{2}=6.95 \\
p=0.40\end{array}$ & $\begin{array}{l}\chi^{2}=28.08 \\
p<0.0001\end{array}$ \\
\hline $\begin{array}{l}\text { nonlocal gun } \\
\text { hunters }\end{array}$ & $0.42(55)$ & $0.67(55)$ \\
\hline local trappers & 0.42 (19) & 0.11 (18) \\
\hline local gun hunters & $0.53(32)$ & $0.31(32)$ \\
\hline nonlocal trappers & $0.13(15)$ & $0.6(15)$ \\
\hline $\begin{array}{c}\text { occasional } \\
\text { hunters }\end{array}$ & $0.5(10)$ & $0.1(10)$ \\
\hline Simple & $\begin{array}{c}\chi^{2}=1.50 \\
p=0.22\end{array}$ & $\begin{array}{c}\chi^{2}=2.47 \mathrm{e}-31 \\
p=1\end{array}$ \\
\hline $\begin{array}{l}\text { high-impact } \\
\text { hunters }\end{array}$ & $0.60(15)$ & $0.43(14)$ \\
\hline $\begin{array}{c}\text { low-impact } \\
\text { hunters }\end{array}$ & $0.40(116)$ & $0.54(116)$ \\
\hline All hunters & $0.42(131)$ & $0.45(130)$ \\
\hline
\end{tabular}

associated with clusters $\left(n=130, \chi^{2}=28.08, \mathrm{df}=4, p<\right.$ $0.0001)$, but not the simple target groups of low-versus high-impact hunters ( $\left.\chi^{2}=1.09 \mathrm{e}-31, \mathrm{df}=1, p=1.00\right)$. In the largest cluster, nonlocal gun hunters, $67 \%$ of hunters had a catch confiscated, but only $11 \%$ of local trappers had a catch confiscated, the second largest cluster.

\section{Discussion}

Valuable insights for intervention design were obtained from a cluster method to subdivide households and hunters. By contrast, the simple approach of defining target groups based only on hunting impact (hunting households and high-impact hunters) was relatively uninformative with respect to targeting because these groups had profiles that were similar to the general population. Cluster profiles offered a basis to improve intervention targeting and differentiated groups that are likely to differ in responsiveness to regulatory and livelihood mechanisms, despite being limited to basic livelihood and behavior variables. This implies that segmentation could be successfully applied in many conservation settings, with further advantages expected from dedicated studies that more directly focus on human behavior. Effective targeting is likely to be achieved by considering multiple variables to define target groups, whereas using overly simplistic criteria or failing to define target groups at all may contribute to poorly designed interventions.

Cluster profiles gave insight into targeting of livelihood support interventions and provided a compelling case that distinct needs of different groups are important considerations for intervention design. For instance, the 2 largest hunter clusters, nonlocal gun hunters and local trappers, differed notably in prevalence of cocoa 
and palm farming. Livelihood support programmes which aim to increase income from cocoa and palm farming are commonly implemented across West Africa, often based on the assumption that supporting these livelihoods will lead to a decrease in hunting (Roe et al. 2015). Our findings imply that supporting cocoa or palm farmers may be appropriate for local trappers, but a significant subset of hunters, the nonlocal gun hunters, currently have little involvement in these activities and thus are unlikely to participate. This was mirrored at the household level, with the largest cluster comprising mainly cocoa farmers (89\%), whereas only $27 \%$ of the nonlocal farmer cluster had cocoa plantations. This pattern could be due to barriers preventing nonlocal citizens from farming cocoa, such as challenges of land-tenure security or a stronger preference for shorter term investments due to plans to return to their original home (Sward 2017; S.J., personal observation). The simple approach to defining target groups masked this pattern and could lead managers toward a more simplistic impression that cocoa is relatively prevalent among high-impact hunters or hunting households.

Participation in livelihood programmes and exposure to hunting penalties were found to differ between clusters, revealing that current livelihood and law enforcement mechanisms operate differently across sections of society. Given these traits were not differentiated between groups defined simply as having high versus low hunting impact, this supports an argument that clustering identifies groups with distinct requirements when it comes to intervention design, whereas simpler approaches may not. Ways to improve both the effectiveness and equitability of interventions could be revealed by determining the mechanisms behind these patterns. For instance, households in the nonlocal farmer cluster had lower rates of participation in pilot-phase livelihood support programmes than the local farmers, suggesting that such programmes may not be equally accessible to both groups. We also found that most hunters in the cluster of nonlocal gun hunters had been penalized for hunting (67\%), whereas this was far lower among local trappers (11\%). Reasons for this could include trading patterns, because local trappers may export a smaller proportion of catch and face less risk of confiscation. However, bias in the enforcement of laws may also play a role because locals could be expected to have stronger interpersonal relationships with park staff. Evidently, these penalties had proven ineffective as hunting deterrents for those in our sample, whereas any individuals who had ceased hunting due to law enforcement efforts would not have been included in our study. In contrast, killing of large-bodied protected species did not differ for clusters or simply defined groups, suggesting that neither segmentation approach could offer insight for targeting when it comes to this aspect of hunting behavior. Whether or not hunters had killed protected species during their career may represent an imprecise indicator of multiple factors, including hunters' skill, methods, and awareness of protected species laws, which do not appear to have been captured in the cluster analysis.

An unforeseen advantage of segmentation may be to help identify potentially vulnerable groups within the population. We found a relatively small subset of households, the nonlocal hunting household cluster, had a high prevalence of hunting but relatively few other income sources and particularly low participation in shifting agriculture or plantation cropping. As incomers, these households do not have equal status with local citizens when it comes to many aspects of land tenure, decision making, or local judicial processes and could face high costs of hunting reductions that may not be adequately offset by agricultural livelihood support. Nonlocal citizens had typically distinct livelihood portfolios and hunting behavior from locals, both at the scale of households and individual hunters. Kümpel et al. (2009) similarly found that immigrant hunters have distinct behavioral profiles from locals. This pattern is particularly relevant in the context of community-based natural resource management which seeks to shift control of resources to local management bodies while ensuring that opportunity costs are not unduly borne by the poorest (Duffy et al. 2016). A major challenge is ensuring equitable distribution of benefits and power (Law et al. 2018), and marginalization of nonlocal immigrants could be a concern, particularly if livelihood patterns are a result of inequalities such as land tenure rights.

Our case study describes a promising first step in developing segmentation as a tool in site-based conservation. However, further work is required to realize the potential of this technique, particularly when it comes to identifying appropriate variables for clustering. Many aspects of behavior are likely to be underpinned by psychographic traits such as risk attitudes and personality (Boslaugh et al. 2005; Hunecke et al. 2010; Wolff et al. 2010) and an understanding of these could generate deeper insight for intervention design. Moving beyond socioeconomic descriptions toward approaches drawing on behavioral theory and fields such as psychology may do much to improve intervention design (Saunders et al. 2006; Bennett et al. 2017; St John et al. 2018) and leverage the potential of tools such as audience segmentation. There is also a need to place relevant psychosocial attributes more squarely at the heart of monitoring programs to improve understanding of factors that facilitate behavior-change outcomes.

Translating cluster attributes into practical recommendations for intervention design requires a rigorous process of testing and development (Verissimo et al. 2011), which can be facilitated by adaptive management (McCarthy \& Possingham 2007). An important limitation of our study is that we did not directly assess peoples' responses to interventions. A priority for future 
segmentation studies should be to integrate a robust validation of groups into the monitoring and development process, based on direct measures of behavior (Boslaugh et al. 2005). This will also contribute to understanding of behavior-change mechanisms more generally and build a stronger evidence base to guide decision making. Segmentation analysis over larger scales could generate valuable insights for regional conservation planning, and an interesting question remains of whether cluster profiles identified in our study are consistent at other sites.

Given its current role in social and commercial marketing applications, audience segmentation could be a valuable tool that is relevant in many conservation settings. The approach of defining population structure across multiple variables provides managers with a more comprehensive view of who they intend to influence. This promotes the view that populations are composed of heterogeneous groups and places their different needs and behavior at the center of decision making. Our case study demonstrates that segmentation can be informative even when only basic livelihood data sets are used, and we encourage more widespread adoption of the approach within the conservation community.

\section{Acknowledgments}

We thank the Forestry Development Authority of Liberia for permission to conduct this study. We also thank Tonglay, Normon, and Zuie clans and each of the communities that participated. We thank the Society for Conservation of Nature of Liberia and the staff of the GolaMA project, with special thanks for M. Garbo, A. Gardner, and the field research team. Finally, we thank the Royal Society for the Protection of Birds and the European Union for supporting this work.

\section{Supporting Information}

Livelihood and behavior profiles of groups defined using the cluster and simple methods (Appendix S1), sociodemographic descriptions of groups defined using the cluster and simple methods (Appendix S2), demographic information (Appendix S3), and questionnaires administered to households and hunters (Appendix S4) are available online. The authors are solely responsible for the content and functionality of these materials. Queries (other than absence of the material) should be directed to the corresponding author.

\section{Literature Cited}

Agrawal A, Gibson CC. 1999. Enchantment and disenchantment: the role of community in natural resource conservation. World Development 27:629-649.
Ajzen I. 2011. The theory of planned behaviour: reactions and reflections. Psychology \& Health 26:1113-1127.

Anable J. 2005. Complacent car addicts' or 'aspiring environmentalists'? Identifying travel behaviour segments using attitude theory. Transport Policy 12:65-78.

Benítez-López A, Alkemade R, Schipper AM, Ingram DJ, Verweij PA, Eikelboom JAJ, Huijbregts MAJ. 2017. The impact of hunting on tropical mammal and bird populations. Science 356:180-183.

Bennett NJ, et al. 2017. Mainstreaming the social sciences in conservation. Conservation Biology 31:56-66.

Boslaugh SE, Kreuter MW, Nicholson RA, Naleid K. 2005. Comparing demographic, health status and psychosocial strategies of audience segmentation to promote physical activity. Health Education Research 20:430-438.

Cronin DT, et al. 2017. Conservation strategies for understanding and combating the primate bushmeat trade on Bioko Island, Equatorial Guinea. American Journal of Primatology 79 (e22663) https:// doi.org/10.1002/ajp.22663.

Davies G. 2002. Bushmeat and international development. Conservation Biology 16:587-589.

Dietrich T, Rundle-Thiele S, Schuster L, Drennan J, Russell-Bennett R, Leo C, Gullo MJ, Connor JP. 2015. Differential segmentation responses to an alcohol social marketing program. Addictive Behaviors 49:68-77.

Duffy R, St John FAV, Büscher B, Brockington D. 2016. Toward a new understanding of the links between poverty and illegal wildlife hunting. Conservation Biology 30:14-22.

Fa JE, Currie D, Meeuwig J. 2003. Bushmeat and food security in the Congo Basin: linkages between wildlife and people's future. Environmental Conservation 30:71-78.

Forthofer MS, Bryant CA. 2000. Using audience-segmentation techniques to tailor health behavior change strategies. American Journal of Health Behavior 24:36-43.

Gavin MC, Solomon JN, Blank SG. 2010. Measuring and monitoring illegal use of natural resources. Conservation Biology 24: 89- 100 .

Geweke J. 1992. Evaluating the accuracy of sampling-based approaches to the calculation of posterior moments. Pages 169-193 in Bernardo JM, Berger JO, Dawid AP, Smith AFM, editors. Bayesian statistics. 4. Clarendon Press, Oxford.

Greengrass E. 2016. Commercial hunting to supply urban markets threatens mammalian biodiversity in Sapo National Park, Liberia. Oryx 50:397-404.

GRNP (Gola Rainforest National Park). 2015. Gola Rainforest National Park website. Available from https://www.golarainforest.org/ gola-liberia (accessed November 2018).

Hardcastle SJ, Hagger MS. 2016. Psychographic profiling for effective health behavior change interventions. Frontiers in Psychology 6:1988.

Harrison M, Baker J, Twinamatsiko M, Milner-Gulland EJ. 2015. Profiling unauthorized natural resource users for better targeting of conservation interventions. Conservation Biology 29:16361646.

Hoyt R. 2004. Wild Meat Harvest and Trade in Liberia: managing biodiversity, economic and social impacts. Overseas Development Institute wildlife policy briefing number 6. Overseas Development Institute, London.

Hunecke M, Haustein S, Böhler S, Grischkat S. 2010. Attitude-based target groups to reduce the ecological impact of daily mobility behavior. Environment and Behavior 42:3-43.

Jones KE, et al. 2009. PanTHERIA: a species-level database of life history, ecology, and geography of extant and recently extinct mammals. Ecology 90:2648.

Junker J, Boesch C, Mundry R, Stephens C, Lormie M, Tweh C, Kühl HS. 2015. Education and access to fish but not economic development predict chimpanzee and mammal occurrence in West Africa. Biological Conservation 182:27-35. 
Kingdon J. 2015. The Kingdon field guide to African mammals. 2nd edition. Princeton University Press, Princeton, New Jersey.

Kotler P, Lee N. 2008. Social marketing influencing behaviors for good. Sage Publications, Thousand Oaks, California.

Kümpel NF, Rowcliffe JM, Cowlishaw G, Milner-Gulland EJ. 2009. Trapper profiles and strategies: insights into sustainability from hunter behaviour. Animal Conservation 12:531-539.

Law EA, Bennett NJ, Ives CD, Friedman R, Davis KJ, Archibald C, Wilson KA. 2018. Equity trade-offs in conservation decision making. Conservation Biology 32:294-303.

Lee YO, Jordan JW, Djakaria M, Ling P. 2014. Using peer crowds to segment black youth for smoking intervention. Health Promotion Practice 15:530-537.

Maibach EW, Leiserowitz A, Roser-Renouf C, Mertz CK. 2011. Identifying like-minded audiences for global warming public engagement campaigns: an audience segmentation analysis and tool development. PLOS ONE 6 (e17571) https://doi.org/10.1371/ journal.pone.0017571.

McCarthy MA, Possingham HP. 2007. Active adaptive management for conservation. Conservation Biology 21:956-963.

McKenzie-Mohr D, Lee NR, Kotler P, Schultz PW. 2011. Social marketing to protect the environment: what works. Sage Publications, Thousand Oaks, California.

Nuno A, St John FAV. 2014. How to ask sensitive questions in conservation: a review of specialized questioning techniques. Biological Conservation 189:5-15.

Ordaz-Németh I, et al. 2017. The socio-economic drivers of bushmeat consumption during the West African Ebola crisis. PLOS Neglected Tropical Diseases 11(3) (e0005450) https://doi.org/ 10.1371/journal.pntd.0005450.

Papastamoulis P. 2014. Handling the label switching problem in latent class models via the ECR algorithm. Communications in Statistics Simulation and Computation 43:913-927.

Papastamoulis P, Rattray M. 2017. BayesBinMix: an R package for model based clustering of multivariate binary data. R Journal 9:403420.

Poortinga W, Darnton A. 2016. Segmenting for sustainability: the development of a sustainability segmentation model from a Welsh sample. Journal of Environmental Psychology 45:221-232.

R Core Development Team. 2014. R: a language and environment for statistical computing. Available from www.R-project.org (accessed November 2017).

Reddy SM, Montambault J, Masuda YJ, Keenan E, Butler W, Fisher JR, Asah ST, Gneezy A. 2017. Advancing conservation by understanding and influencing human behavior. Conservation Letters 10:248-256.
Rimal RN, Brown J, Mkandawire G, Folda L, Böse K, Creel AH. 2009. Audience segmentation as a social-marketing tool in health promotion: use of the risk perception attitude framework in HIV prevention in Malawi. American Journal of Public Health 99:2224-2230.

Roe D, et al. 2015. Are alternative livelihood projects effective at reducing local threats to specified elements of biodiversity and/or improving or maintaining the conservation status of those elements? Environmental Evidence 4:1-22.

Saunders CD, Brook AT, Myers OE. 2006. Using psychology to save biodiversity and human well-being. Conservation Biology 20:702705.

Spiteri A, Nepal SK. 2006. Incentive-based conservation programs in developing countries: a review of some key issues and suggestions for improvements. Environmental Management 37:1-14.

St John FAV, Linkie M, Martyr DJ, Milliyanawati B, McKay JE, Mangunjaya FM, Leader-Williams N, Struebig MJ. 2018. Intention to kill: tolerance and illegal persecution of Sumatran tigers and sympatric species. Conservation Letters 11:1-8.

Sward J. 2017. In-migration, customary land tenure, and complexity: exploring the relationship between changing land tenure norms and differentiated migrant livelihoods in Brong Ahafo, Ghana. Population and Environment 39:87-106.

van Vliet N. 2011. Livelihood alternatives for the unsustainable use of bushmeat. Report prepared for the CBD Bushmeat Liaison Group. Technical series 60. Secretariat of the Convention on Biological Diversity, Montreal.

Veríssimo D. 2013. Influencing human behaviour: an underutilised tool for biodiversity management. Conservation Evidence 10:29-31.

Verissimo D, MacMillan DC, Smith RJ. 2011. Toward a systematic approach for identifying conservation flagships. Conservation Letters 4:1-8.

Wedel M, Kamakura WA. 2012. Market segmentation: conceptual and methodological foundations. 8. Kluwer, Dordrecht, the Netherlands.

Wolff LS, Massett HA, Maibach EW, Weber D, Hassmiller S, Mockenhaupt RE. 2010. Validating a health consumer segmentation model: behavioral and attitudinal differences in disease prevention-related practices. Journal of Health Communication 15:167-188.

Wright AJ, et al. 2015. Competitive outreach in the 21st century: why we need conservation marketing. Ocean and Coastal Management 115:41-48.

Zabala A, Pascual U, García-Barrios L. 2017. Payments for pioneers? Revisiting the role of external rewards for sustainable innovation under heterogeneous motivations. Ecological Economics 135:234245. 